\title{
Invasive ants of continental Ecuador, a first account
}

\author{
David A Donoso ${ }^{1}$, Giovanni Onore ${ }^{2}$, Giovanni Ramón ${ }^{3}$, John E Lattke ${ }^{4}$ \\ ${ }^{1}$ Museo de Colecciones Biológicas, MUTPL, Departamento de Ciencias Naturales, Universidad Técnica Particular de Loja, \\ Loja, Ecuador \\ ${ }^{2}$ Fundación Otonga, Apartado 17-03-1514A, Quito, Ecuador \\ ${ }^{3}$ Instituto Nacional de Investigación en Salud Pública, Quito, Ecuador \\ ${ }^{4}$ Investigador Prometeo, Dirección de Investigación, Programa de Investigación Biodiversidad, Bosques y Servicios Ecosis- \\ témicos, Universidad Nacional de Loja, EC 110101 Loja, Ecuador
}

david.donosov@gmail.comＲecibido: 2014-04-07; aceptado: 2014-10-02

\section{RESUMEN.-}

El manejo de las especies invasoras es considerado uno de los grandes desafíos que impone el Cambio Global a nuestras sociedades, junto con la deforestación y el calentamiento de la atmósfera. Se conoce muy poco sobre las hormigas invasoras en el Ecuador continental, incluso cuando se ha demostrado en el resto del mundo su agresividad, los impactos negativos en los ecosistemas y las pérdidas económicas que causan. La mayoría de registros de hormigas invasoras en el Ecuador provienen de las Islas Galápagos y no existe un inventario de ellas para el Ecuador continental. Aquí compilamos registros de hormigas invasoras presentes en la literatura y en colecciones entomológicas locales para crear la primera lista de hormigas invasoras presentes en el Ecuador continental. Se registra la presencia de un total de 16 especies de hormigas invasoras. De estas, diez especies son extranjeras, pero invasoras en el Ecuador; y seis especies son nativas en el Ecuador e invasoras en el exterior. Proveemos los primeros registros para Ecuador continental de Cardiocondyla minutior, Monomorium floricola, Monomorium pharaonis, Tapinoma melanocephalum, y Tetramorium bicarinatum. Ademas, los registros de Cardiocondyla wroughtonii y Tetramorium lucayanum son los primeros para el país.

PALABRAS CLAVES: especies invasoras, especies exóticas, especies vagabundas, fauna continental, nuevos registros

\begin{abstract}
.-
Management of invasive species is considered one of the great challenges deriving from Global Change that our societies currently face, besides deforestation and the warming of the atmosphere. Little is known about the invasive ants in continental Ecuador, despite the world-wide demonstrated aggressiveness, negative ecological impact, and economic losses caused by them. Most Ecuadorian records are from the Galápagos Islands and there is yet no inventory for the mainland. Gleaning records from the literature and local entomological collections, we present the first list of invasive ants present on mainland Ecuador. A total of 16 invasive ant species are recorded. Ten ant species are foreign to the country. The remaining six ant species are native to Ecuador and invasive elsewhere. Records of Cardiocondyla minutior, Monomorium floricola, Monomorium pharaonis, Tapinoma melanocephalum, and Tetramorium bicarinatum are the first ones for continental Ecuador. Furthermore, Cardiocondyla wroughtonii and Tetramorium lucayanum are reported for the first time for the country.
\end{abstract}

KEYWORDS: continental fauna, exotic species, invasive species, new records, tramp species 


\section{INTRODUCTION}

Invasive species are a set of species found outside their native or usual range. There are at least two reasons why these species are successfully dispersed to new habitats. First, human activities are increasingly homogenizing the planet (Groffman et al., 2014). Second, the enhanced connectivity of different landscapes due to human communication and transportation systems provides ample opportunities for species to disperse (Hulme 2009). Invasive species can remain unnoticed, without interfering with human activities (agriculture, housing, etc) and natural systems. But more than often, these species become dominant, displacing local communities (Guénard and Dunn 2010; Hejda et al., 2009; Mooney and Cleland 2001) and causing great impact on local economies (Pimentel et al., 2005). Invasive species may then become a serious threat to biodiversity at local and global scales with considerable environmental, economical and cultural consequences.

Amongst the most noxious invasive species, the ants (Hymenoptera: Formicidae) are a cosmopolitan group of insects that have gained a lot of attention in the last years for their aggressiveness and impacts on local ecosystems (Holway et al., 2002; Lowe et al., 2000). Once invasive ants colonize a new area, they may rapidly increase their numbers and displace local species by direct and indirect competition (Chapman and Bourke 2001). In economic terms, it has been estimated that one ant species, the fire ant Solenopsis invicta, incurs in damages for up to $\$ 1$ billion (Pimentel et al., 2005) just in the US. The study of the impacts of invasive ants on oceanic islands has received a lot of attention, especially regarding the impacts on the vulnerable native fauna (e.g. Davis et al., 2010; Wetterer 2007; O'Dowd et al., 2003). In the last years, however, more studies have found that the effects of invasive ants on continental ecosystems may be just as dramatic as those on islands (e.g. Dunham y Mikheyev 2010, Dejean et al., 2007).
Little is known about invasive ant species in continental Ecuador when compared with the better known Galápagos Islands fauna (Herrera 2014). Even worldwide invasive species as the argentine ant (Linepithema humile) and the crazy ant (Paratrechina longicornis), long time known to inhabit in Ecuadorian territories, have not been previously reported for the country in formal revisions or catalogs (Wetterer 2008, Fernandez y Sendoya 2004, Shattuck 1994) On the other side, regionally distributed ants, such as the ghost ant (Tapinoma melanocephalum) and the penny ant (Tetramorium bicarinatum), while previously reported in Ecuador, have not received any attention from local authorities. Until now, it is unknown the economic impact that many invasive species in general, and invasive ant species in particular, may have in the Ecuadorian economy.

\section{MATERIALS AND METHODS}

We gather information on invasive ant species from unpublished and published sources. We reviewed unpublished material at local ant collections (CISEC - Colección de Invertebrados delSur del Ecuador, UTPL, Loja, Ecuador; QCAZ - Quito Catholic Zoology Museum, PUCE, Quito, Ecuador). Published records were obtained through search engines, Google Scholar and ISI Web of Knowledge, with the couples [invasive] "and" [ant "or" Formicidae] "and" [Ecuador]. We also cross-reference known literature to find reports of invasive ant species in Ecuador. Additionally, records in AntWeb (Fisher 2011) and the Global Biodiversity Information Facility (GBIF 2014) databases were gathered. To increase the number of unpublished records, we visited nearby markets and ports.

\section{RESULTS}

A total of 16 invasive ant species are recorded. Ten ant species are foreign to the country. The remaining six ant species are native to Ecuador and invasive elsewhere. We provide the first records for seven of these species. We divide our account among those invasive ant species that coming from overseas $(n=10)$ and those native 
to Ecuador, but invasive overseas $(n=6)$. All literature and specimen records are for mainland Ecuador.

Foreign ant species, invasive to Ecuador.Cardiocondyla minutior (Forel, 1899). Possibly native to SE Asia (Seifert 2003). Specimen record: Orellana, Yasuni, $-0.671389^{\circ}-76.700556^{\circ}$, 250m, VII.2008, D.A. Donoso col., 3w, CISEC, D. Donoso det.

Cardiocondyla wroughtonii (Forel, 1890). Probably native to SE Asia (Bolton 1982). Specimen record: Loja, Alamala, ca. Catamayo, $-3.986246^{\circ}$ $-79.425890^{\circ}, 1628 \mathrm{~m}, 12 . X \mathrm{I}-\mathrm{XII} .2013$, A. Castro col., $1 \mathrm{w}$, CISEC, J. Lattke det. In dry scrub vegetation.

Linepithema humile (Mayr 1868). Native to South Brazil, Paraguay and Argentina (Wild 2004). Literature records: Pichincha (Wetterer et al., 2009, Wild 2004), Tungurahua (Antweb 2011). Specimen records: Pichincha, Quito, 1.X.2002, $-0.1895^{\circ}-78.4939^{\circ}, 2732 \mathrm{~m}$, M.F.Salvador col., $>5 \mathrm{w}$, QCAZ (Antweb 2014); Pichincha, Quito Norte, I.18.2002,-0.1833 $-78.5^{\circ}, 2732 \mathrm{~m}$, T. Vries col., $>5 \mathrm{w}$, QCAZ (Antweb 2014); Pichincha, Carapungo, 30.XI.2003, $-0.0877^{\circ}-78.4493^{\circ}, 2600 \mathrm{~m}$, A.L. Wild col., >5w, ALWC (Antweb 2014); Pichincha, Mitad del Mundo, at monument, 7.XII.2003, $-0.0021^{\circ}-78.4563^{\circ}, 2483 \mathrm{~m}$, A.L. Wild col., $>5 \mathrm{w}$, ALWC (Antweb2014). In park surrounding the Mitad del Mundo monument. Irrigated artificial turf with ornamentals.

Monomorium floricola (Jerdon, 1851). Probably native to Asia (Wetterer 2010). Specimen records: Orellana, Yasuni, -0.671389 $-76.700556^{\circ}$, 250m, VII.2008, D.A. Donoso, 7w, CISEC, D. Donoso det.

Monomorium pharaonis (Linnaeus, 1758). Native to either the Asian (Wetterer 2010c) or African Tropics (Tausan y Marko 2011; Bolton 1987; Klots y Klots 1959). Specimen records: Orellana, Yasuni, -0.671389 ${ }^{\circ}-76.700556^{\circ}$, 250m, VII.2008, D.A. Donoso col., 10w, CISEC, D. Donoso det; Pichincha, Quito, Calle Ritter, -0.199297 $-78.511100^{\circ}, 2900 \mathrm{~m}, 13 . \mathrm{VIII} .2013$, G. Onore col., 20w. CISEC, D. Donoso. Urban environment. These are the first records for mainland Ecuador.
It was incorrectly reported for the country by Fernandez and Sendoya 2004 and Wetterer 2010b. Biology notes: It seems the ants are concentrated mainly on houses near water sources. In the kitchen, they are attracted by left overs of cooked eggs, fish, meat, cakes, grumes, stock cube, and dry almond [Prunus dulcis (Mill.) D.A. Webb]. All over the infested area, the ants explore the floor, wall voids, electrical and water conduits, computer, electrical devices, tooth brushes, combs, clothes, shoes and socks, books, food storage boxes and bags especially if used as containers of starch or oily processed products. The ants devoured several dry insects stored in an uncovered entomological drawer over the course of a night, and in the morning, only insect wings and pins were found. Following the ants trail, nests were found under the tiles covering the wall and the ants reach the colony though tiny holes.

Paratrechina longicornis (Latreille, 1802). Apparently native to SE Asia (Wetterer 2008). Literature records: A world wide distribution map in Wetterer 2008 shows at least 2-3 records from mainland Ecuador but no detailed locality information is given.

Strumigenys rogeri (Emery, 1890). Native to Africa (Bolton 2000). Literature records: Santo Domingo de los Tsáchilas (Wetterer 2012).

Tapinoma melanocephalum (Fabricius, 1793). Possibly native to the Indo-Pacific Region (Wetterer 2009). Specimen records: Orellana, Yasuni, -0.671389 -76.700556 , 250m, VII.2008, D.A. Donoso col., $7 \mathrm{w}$, CISEC, D. Donoso det.

Tetramorium bicarinatum (Nylander, 1846). Native to Africa (Bolton 1980). Specimen records: Pichincha, Otongachi, $-0.313611^{\circ}-78.954167^{\circ}$, 850m, 6.VIII.2009, G. Ramón col., 2w, QCAZ, J. Lattke det. Cloud forest.; Sucumbios, $-0.859167^{\circ}$ $-76.311944^{\circ}, 250 \mathrm{~m}$, V.2005, D.A. Donoso, 7w, 5q, CISEC, J. Lattke det.

Tetramorium lucayanum Wheeler, 1905. Native to Africa (Wetterer 2011). Specimen records: Pichincha, La Unión del Toachi (Otongachi), 
$-0.313611^{\circ}-78.954167^{\circ}, 850 \mathrm{~m}, 6 . \mathrm{VIII} .2009, \mathrm{G}$. Ramón col., 2w, QCAZ, J. Lattke det. Cloud forest; Napo, Tena, 21.XII.2011, $-0.98881^{\circ}$ $-77.82354^{\circ}, 510 \mathrm{~m}$, J. Longino col., 1w, JTLC, JTL7741 (Antweb 2014), Urban area. Biology notes: Despite ten successive years of regularly collecting ants in the Otongachi Reserve by D. Donoso, and G. Ramón only two specimens have been collected. This corroborates other observations that imply this species seems to be an inconspicuous member of ant communities when invasive outdoors and with possibly little impact (Wetterer 2011)

Ecuadorian ant species, invasive elsewhere.Gnamptogenys triangularis (Mayr 1887). Native to most of South America (Lattke 1995). Invasive in South East USA (MacGown and Wetterer 2012). Literature records: Los Rios (Lattke 1995); Pichincha (Lattke et al., 2004). Specimen record: Pichincha, $47 \mathrm{~km} S$ Santo Domingo de los Colorados (Estación Río Palenque), 23.V.1975, S. and J Peck, col., 3w, MIZA, J. Lattke det.

Pachycondyla stigma (Fabricius 1804). Native to the New World tropics, invasive in Indo-Australia and Orient (Wetterer 2012). Literature records: Santo Domingo de los Tsáchilas (Mackay and Mackay 2010, Santchi 1913); Esmeraldas (Mackay and Mackay 2010); Guayas (Mackay and Mackay 2010); Imbabura (Mackay and Mackay 2010); Los Rios (Mackay and Mackay 2010); Napo (Mackay and Mackay 2010); Pichincha (Mackay and Mackay 2010); Sucumbíos (Mackay and Mackay 2010); Orellana (Salazar and Donoso 2013).

Pseudomyrmex gracilis (Fabricius 1804). Native to South America, with invasive populations expanding in the Carribean, Hawaii and southeast USA (Wetterer 2010a). Literature records: Guayas (Forel 1907); Orellana (Ryder et al., 2010).

Wasmannia auropunctata (Roger 1863). Native from Mexico to South America (Wetterer and Porter 2003), with invasive outdoor populations in Africa, the Middle East, and Indo-Australia (Wetterer 2013). Literature records: Santo Domingo de los Tsáchilas (Donoso and Ramon 2009); Orellana (Salazar and Donoso
2013, Ryder et al., 2010, Mert et al., 2009, Ryder et al., 2007)

Solenopsis geminata (Fabricius 1804) Native from southern US to northern South America (Trager 1991). Literature records: Galápagos (Wetterer 2011; Kempf 1972; Creighton 1930); Orellana (Salazar and Donoso 2013; Plowes et al., 2007); Sucumbios (Plowes et al., 2007)

Solenopsis virulens (Smith 1858). Native to South America (Trager 1991). Literature records: Orellana (Ryder et al., 2010; Ryder et al., 2007); Sucumbios (Salazar and Donoso 2013).

\section{DISCUSSION}

Little is known about invasive ants in continental Ecuador as most invasive biota studies for the country center around the Galápagos Islands. While this bias is understandable given the extraordinary biological and historical heritage of these islands, the impact of invasive ants in the mainland could be greater. Most of Ecuador's biological diversity is on tierra firme, as well as most of the human population, and most of the nature conservation problems. Here we gather together sparse literature records and museum specimen information about the distribution of 16 invasive ants in the mainland.

We know nothing about the possible impacts of the ant in both artificial and native ecosystems. The case of Monomorium pharaonis in Quito illustrates this point. Workers were first observed in a house in Barrio Miraflores Alto by one of the authors (GO) on 13 April, 2013. Neighboring homes were inspected within a radius of $100 \mathrm{~m}$ with no additional sightings. Thirteen months later, however, the ants occupied an area approximately of $1800 \mathrm{~m} 2$ with a preference for homes, making use of any resource available, including aphid and scale insect honey dew in the gardens. Pharaoh's ant is considered a mayor hazard in hospital and veterinary clinics (Wilson and Booth 1981; Beatson 1972), and the most important hospital in the city is less than $1 \mathrm{~km}$ away from the aforementioned infestation. This publication suggest that a monitoring 
program implemented in the hospital may avoid contamination of sterile areas.

There is, however, much to do, starting with more field work to collect and better gauge the spread of these species throughout the mainland, and detect additional invasives which may already be present, but do not appear in the literature or museum records: Cardiocondyla emeryi Forel 1881, Cardiocondyla nuda (Mayr, 1866), Monomorium destructor (Jerdon, 1851), and Pheidole megacephala (Fabricius, 1793). The list of invasive species known from the Galápagos are probably a good starting point to guide the search for potential mainland invasives, though more mesic loving species may not be present on the islands. We recommend searching in port cities, especially in the local food markets for increasing the known number of invasives. Large infrastructure projects involving the importation of considerable amounts of heavy equipment and other goods are also deemed as candidates for finding invasives, and further spreading those already present.

Given the potential impact of invasive ants in terms of ecosystem functionality, economic losses in agriculture and food commercialization chains, public health problems, and being a general nuisance, we urge further research to fully assess the presence, present and potential impact of these species, and devise schemes to manage the problems.

\section{ACKNOWLEDGEMENTS}

This publication was financed in part by UTPL Grant \# PROY_CCNN_0022 to DAD. JEL received support from the Prometeo Project of the Secretary for Higher Education, Science, Technology, and Innovation (SENESCYT) of the Republic of Ecuador.

\section{REFERENCES}

Beatson SH. 1972. Pharaoh ants as pathogen vectors in hospitals. Lancet, 1: 425-427.
Bolton B. 1980. The ant tribe Tetramoriini (Hymenoptera: Formicidae). The genus Tetramorium Mayr in the Ethiopian zoogeographical region. Bulletin of the British Museum (Natural History). Entomology, 40: 193-384.

Bolton B. 1982. Afrotropical species of the myrmicine ant genera Cardiocondyla, Leptothorax, Melissotarsus, Messor and Cataulacus (Formicidae). Bulletin of the British Museum (Natural History). Entomology, 45: 307-370.

Bolton B. 1987. A review of the Solenopsis genus- group and revision of Afrotropical Monomorium Mayr (Hymenoptera: Formicidae). Bulletin of the British Museum (Natural History). Entomology, 54: 263-452

Bolton B. 2000. The ant tribe Dacetini. Memoirs of the American Entomological Institute, 65: 1-1028.

Chapman RE y Bourke AF. 2001. The influence of sociality on the conservation biology of social insects. Ecology Letters, 4(6): 650-662.

Creighton WS. 1930. The New World species of the genus Solenopsis (Hymenoptera: Formicidae). Proceedings of the American Academy of Arts and Sciences 66: 39-151.

Davis NE, O'Dowd DJ, Mac Nally R y Green PT. 2010. Invasive ants disrupt frugivory by endemic island birds. Biology Letters, 6(1): 85-88.

Dejean A, Kenne M y Moreau C. 2007. Predatory abilities favour the success of the invasive ant Pheidole megacephala in an introduced area. Journal of Applied Entomology, 131(9-10): 625-629.

Donoso DA y Ramón G. 2009. Composition of a high diversity leaf litter ant community (Hymenoptera: Formicidae) from an Ecuadorian pre-montane rainforest. Annales de la Société Entomologique de France (n.s.), 45(4): 487-499. 
Dunham AE y Mikheyev AS. 2010. Influence of an invasive ant on grazing and detrital communities and nutrient fluxes in a tropical forest. Diversity and Distributions, 16(1): 33-42.

Emery C. 1890. Studi sulle formiche della fauna neotropica. Bollettino della Società Entomologica Italiana, 22: 38-80.

Fabricius JC. 1793. Entomologia systematica emendata et aucta. Secundum classes, ordines, genera, species, adjectis synonimis, locis observationibus, descriptionibus. Tome 2 . Hafniae: C. G. Proft, 519 pp.

Fabricius JC. 1804. Systema Piezatorum secundum ordines, genera, species, adjectis synonymis, locis, observationibus, descriptionibus. Brunswick: C. Reichard, 16: 30 pp.

Fernández F y Sendoya S. 2004. Lista sinonímica de las hormigas Neotropicales (Hymenoptera: Formicidae). Biota Colombiana, 5: 3-105.

Fisher BL. 2011. AntWeb: Ants of the World. Available online at: http: / / www.antweb.org.

Forel A. 1881. Die Ameisen der Antille St. Thomas. Mitteilungen der Münchener Entomologischen Verein, 5: 1-16.

Forel A. 1890. Aenictus-Typhlatta découverte de M. Wroughton. Nouveaux genres de formicides. Annales de la Société Entomologique de Belgique, 34: 102-114.

Forel A. 1907. Formiciden aus dem Naturhistorischen Museum in Hamburg. Mitteilungen aus dem Naturhistorischen Museum in Hamburg, 24: 1-20.

GBIF. 2014. Global Biodiversity Information Facility Data Portal. GBIF (Ed.)

Groffman PM, Cavender-Bares J, Bettez ND, Grove JM, Hall SJ, Heffernan J, Hobbie S, Larson KL, Morse JL, Neill C, Nelson
K, O'Neill-Dunne J, Ogden L, Pataki DE, Polsky C, Chowdhury RR y Steele MK. 2014. Ecological homogenization of urban America. Frontiers in Ecology and Environment, 12(1): 74-81.

Guénard B y Dunn RR. 2010. A new (old), invasive ant in the hardwood forests of eastern North America and its potentially widespread impacts. PLoS ONE, 5(7): e11614.

Hejda M, Pysek P y Jarosik V. 2009. Impact of invasive plants on the species richness, diversity and composition of invaded communities. Journal of Ecology, 97(3): 393-403.

Herrera HW. 2014. CDF Checklist of Galápagos Ants - FCD Lista de especies de Hormigas de Galápagos. En: Bungartz F, Herrera H, Jaramillo P., Tirado N, Jiménez-Uzcátegui G, Ruiz D, Guézou A. y Ziemmeck F (eds.). Charles Darwin Foundation Galápagos Species Checklist - Lista de Especies de Galápagos dela Fundación Charles Darwin. Charles Darwin Foundation / Fundación Charles Darwin, Puerto Ayora, Galápagos: http: / / www.darwinfoundation. org / datazone / checklists / terrestrialinvertebrates/formicidae/ Last updated 28 Jan 2014.

Holway DA, Lach L, Suarez AV, Tsutsui ND y Case TJ 2002. The causes and consequences of ant invasions. Annual Review of Ecology and Systematics, 33: 181-233.

Hulme PE. 2009. Trade, transport and trouble: managing invasive species pathways in an era of globalization. Journal of Applied Ecology, 46(1): 10-18.

Jerdon TC. 1851. A catalogue of the species of ants found in Southern India. Madras Journal of Literature and Science, 17: 103-127. 
Kempf WW. 1972. Catálogo abreviado das formigas da região Neotropical. Studia Entomologica, 15: 3-344.

Klots A y Klots E. 1959. Living insects of the world. Garden City, New York: Doubleday and Company Inc.

Lattke JE. 1995. Revision of the ant genus Gnamptogenys in the New World (Hymenoptera: Formicidae). Journal of Hymenoptera Research, 4: 137-193.

Lattke JE, Fernández F y Palacio E. 2004. Una nueva especie de Gnamptogenys (Hymenoptera: Formicidae) y comentarios sobre las especies del género en Colombia y Ecuador. Iheringia. Serie Zoologia, 94: 341-349,

Linnaeus C. 1758. Systema naturae per regna tria naturae, secundum classes, ordines, genera, species, cum characteribus, differentiis, synonymis, locis. Tomus I. Editio decima, reformata. Holmiae: L. Salvii, 824 pp.

Lowe S, Browne M y Boudlejas S. 2000. 100 of the world's worst invasive alien species. Aliens, 12: 1-12.

MacGown JA y Wetterer JK. 2012. Geographic spread of Gnamptogenys triangularis (Hymenoptera: Formicidae: Ectatomminae). Psyche, 571430: 1-4.

MacKay, WP y MacKay E. 2010. The systematics and biology of the New World ants of the genus Pachycondyla (Hymenoptera: Formicidae). Lewiston, New York: Edwin Mellen Press, xii+642 pp.

Mayr G. 1866. Myrmecologische Beiträge. Sitzungsberichte der Kaiserlichen Akademie der Wissenschaften in Wien. MathematischNaturwissenschaftliche Classe, 53: 484-517.

Mayr G. 1868. Formicidae novae Americanae collectae a Prof. P. de Strobel. Annuario della Società dei Naturalisti e Matematici, 3: 161-178
Mayr G. 1887. Südamerikanische Formiciden. Verhandlungen der Kaiserlich-Königlichen Zoologisch-Botanischen Gesellschaft in Wien, 37: 511-632.

Mertl A, Wilkie K y Traniello JFA. 2009. Impact of flooding on the species richness, density and composition of Amazonian litternesting ants. Biotropica, 41: 633-641.

Mooney HA y Cleland EE. 2001. The evolutionary impact of invasive species. Proceedings of the National Academy of Sciences, 98(10): 5446-5451.

Nylander W. 1846. Additamentum adnotationum in monographiam formicarum borealium Europae. Acta Societatis Scientiarum Fennicae 2: 1041-1062.

O’Dowd DJ, Green PT y Lake PS. 2003. Invasional 'meltdown' on an oceanic island. Ecology Letters, 6(9): 812-817.

PimentelD, Zuniga R y Morrison D. 2005. Update on the environmental and economic costs associated with alien-invasive species in the United States. Ecological Economics, 52(3): 273-288.

Plowes RM, LeBrun EG, Brown BV y Gilbert LE. 2009. A review of Pseudacteon (Diptera: Phoridae) that parasitize ants of the Solenopsis geminata complex (Hymenoptera: Formicidae). Annals of the Entomological Society of America, 102: 937-958.

Roger J. 1863. Die neu aufgeführten Gattungen und Arten meines Formiciden-Verzeichnisses nebst Ergänzung einiger früher gegebenen Beschreibungen. Berliner Entomologische Zeitschrift, 7: 131-214.

Ryder KT, Mertl AL y Traniello JFA. 2007. Biodiversity below ground: probing the subterranean ant fauna of Amazonia. Naturwissenschaften, 94: 725-731 
Ryder KT, Mertl AL y Traniello JFA. 2010. Species diversity and distribution patterns of the ants of Amazonian Ecuador. PLoS ONE, 5(10): e13146.

Salazar F y Donoso DA. 2013. New ant (Hymenoptera: Formicidae) records for Ecuador deposited at the Carl Rettenmeyer ant collection in the QCAZ Museum. Boletín Tecnico, 11, Serie Zoológica, 8-9: 151-177.

Santschi F. 1913. Hyménoptères. Formicides. En: André, Ern et al. (eds) Mission du service géographique de l'armée pour la mesure d'un arc de méridien équatorial en Amérique du Sud. Paris, Gauthier-Villars.

Seifert B. 2003. The ant genus Cardiocondyla (Insecta: Hymenoptera: Formicidae) - a taxonomic revision of the $C$. elegans, $C$. bulgarica, C. batesii, C. nuda, C. shuckardi, C. stambuloffii, C. wroughtonii, C. emeryi, and C. minutior species groups. Annalen des Naturhistorischen Museums in Wien. B, Botanik, Zoologie, 104: 203-338

Shattuck SO. 1994. Taxonomic catalog of the ant subfamilies Aneuretinae and Dolichoderinae (Hymenoptera: Formicidae). University of California Publications in Entomology 112:i-xix, 1-241

Smith F. 1858. Catalogue of hymenopterous insects in the collection of the British Museum. Part VI. Formicidae. London: British Museum, $216 \mathrm{pp}$.

Tausan I y Marko B. 2011. New records of the Pharaoh ant Monomorium pharaonis (Linnaeus, 1758) (Hymenoptera: Formicidae) in Romania. Entomologica romanica, 16: 23-26.

Trager, J. C. 1991. A revision of the fire ants, Solenopsis geminata group (Hymenoptera: Formicidae: Myrmicinae). Journal of the New York Entomological Society, 99: 141-198.
Wetterer JK. 2007. Biology and impacts of Pacific Island invasive species. 3. The African big-headed ant, Pheidole megacephala (Hymenoptera: Formicidae). Pacific Science, 61(4): 437-456.

Wetterer JK. 2008. Worldwide spread of the long horn crazy ant, Paratrechina longicornis (Hymenoptera: Formicidae). Myrmecological News, 11: 137-149.

Wetterer JK. 2010a. Worldwide spread of the graceful twig ant, Pseudomyrmex Gracilis (Hymenoptera: Formicidae). Florida Entomologist, 93(4): 535-540.

Wetterer JK. 2010b. Worldwide spread of the flower ant, Monomorium floricola (Hymenoptera: Formicidae). Myrmecological News, 13: 19-27.

Wetterer JK. 2010c. Worldwide spread of the pharaoh ant, Monomorium pharaonis (Hymenoptera: Formicidae). Myrmecological News, 13: 115-129.

Wetterer JK. 2011. Worldwide spread of Tetramorium lucayanum (Hymenoptera: Formicidae). Florida Entomologist, 65: 827-831.

Wetterer JK. 2012. Worldwide spread of Roger's dacetine ant, Strumigenys rogeri (Hymenoptera: Formicidae). Myrmecological News, 16: 1-6.

Wetterer JK. 2013. Worldwide spread of the little fire ant Wasmannia auropunctata (Hymenoptera: Formicidae). Terrestrial Arthropod Reviews, 6:173-184

Wetterer JK y Porter SD. 2003. The little fire ant, Wasmannia auropunctata: distribution, impact, and control. Sociobiology, 42:1-41.

Wetterer JK, Wild AL, Suarez AV, Roura-Pascual N y Espadaler X. 2009. Worldwide spread of the Argentine ant, Linepithema humile (Hymenoptera: Formicidae). Myrmecological News, 12: 187-194. 
Wheeler WM. 1905c. The ants of the Bahamas, with a list of the known West Indian species. Bulletin of the American Museum of Natural History, 21:79-135.

Wild AL. 2004. Taxonomy and distribution of the Argentine ant, Linepithema humile (Hymenoptera: Formicidae). Annals of the Entomological Society of America, 97: 1204-1215.
Wilson GR y Booth MJ. 1981. Pharaoh ant control with IGR in hospitals. Pest Control, 49: 14-19. 